\title{
What is Cognitive Historiography, Anyway? Method, Theory, and a Cross-Disciplinary Decalogue
}

\author{
Leonardo Ambasciano ${ }^{1}$ \\ Managing Editor, Journal of Cognitive Historiography \\ Email: leonardo.ambasciano@gmail.com
}

\begin{abstract}
This contribution offers a tentative systemization of different strands of method and theory in the sub-field of cognitive historiography in the form of a decalogue and 30 reflections. The primary aim is to clarify the role of both interdisciplinary collaboration and cross-disciplinary integration. The secondary goal is to provide interested readers, colleagues, and young researchers from a wide range of different academic branches across the two cultures with a crash course and a protocol to basic collaborative research. An indicative and essential bibliography is also provided. This introductory opinion piece is open for further comments, additions, suggestions, and discussions.
\end{abstract}

Keywords: Cognitive historiography; cognition; cross-disciplinary integration; evolution; history; interdisciplinary collaboration.

\section{History Matters}

History is about the recollection, transmission, and interpretation of the past. The study of history employs critical thinking and requires painstaking attention to the multifactorial interactions between chance and necessity, fortuity and pattern, contingency and constraint, unpredictability and serendipity. The first capital sin of any inattentive approach to history is interpreting the past according to what can be ascertained just from contemporary conditions (i.e. presentism).

There is more to history than meets the eye. History is the most ancient form of kinship-tracking, time-keeping, event-recording, relationshipmaintaining, community-building, storytelling-based social cognition of the primate Homo sapiens. As an ultrasocial primate, H. sapiens is naturally primed to invest cognitive and communal resources in the accumulation, elaboration, and exchange of socially relevant information concerning kinship and out-group relations, from family gossip to royal family trees. 
Socio-political prestige is usually assigned to the (purportedly) most ancient and important ancestors, individuals, groups, or ruling dynasties of both in-groups and out-groups. Historical narratives - whether oral or written - are used to store such data through time. However, these narratives are usually part of bigger, overarching, even cosmogonic origin stories which conflate history and myth, fact and fiction, reality and gossip to fill in the gaps of knowledge, offer epistemic satisfaction, make sense of both social and natural environments, and justify the current state of things. Indeed, if history describes $H$. sapiens itself in a nutshell, this ultrasocial primate is also a storytelling animal naturally prone to cognitive biases and intuitive but fallacious heuristics; therefore, historical narratives can be manipulated to accommodate imaginative, counterfactual, or pseudohistorical realities for educational, moralizing, or entertaining purposes, often with the more or less implicit goal to extend and exert control over communities. The second capital sin of a naïve approach to history is thinking, in convenient hindsight, that a given state of things is the inevitable endpoint of a deterministic, teleological force. While simplistic and satisfying, this flawed assumption is liable to ideological, ethnic, nationalistic, or religious exploitations - which the historically savvy individuals should confront by asking, "to the benefit of whom?".

Post-truth, one of such pernicious forms of ideological manipulation specifically based on emotional appeal, is as ancient as humankind itself. To master history is to avoid being misled by post-truth. Always mind the Orwellian warning according to which "Who controls the past controls the future. Who controls the present controls the past". Do not trust your gut. Memory can be deceptive. Folk-historical thinking can be intuitively attention-grabbing but fallacious. Historical data filtered and supplied by interested parties from the past might be incomplete. To avoid committing the third capital sin of an inexperienced approach to history, do not confuse emic testimonies and documents (i.e. first-order, socio-cultural, internal interpretations concerning any society's own origin stories, worldviews, etc.) with etic approaches (that is, second-order, professional, external metainterpretations of first-order data). Most of all, look for the right sources.

\section{History needs Sources}

There is no history without documents. There are no sources without history. By no means should literacy alone be considered the be-all-and-end-all of history.

Sources are anything that carries and encodes any discernible and reliable trace or evidence of the past: DNA, fossils, rocks, isotopes, archaeological 
artefacts, numismatic iconography, ethnographic accounts, anthropological inquiries, artistic records, religious relics, theological debates, behavioural patterns, phonemes, literary and geomythological documentation, folklore, oral traditions, written evidence, textual variants, etc. Their importance and relevance are to be evaluated on a case-by-case basis and always within a larger historiographical picture.

Sources may lie. Documents may be incomplete or corrupted by the passing of time. Documents may be misunderstood, tweaked, fabricated, and exploited to support specific top-down power relations or advance bottomup demands and claims. Historians cannot be neither politically naïve nor gullible. Be always aware of the need to identify the reasons behind any kind of documentary intervention and (mis)interpretation.

\section{History needs Historiography}

There is no interpretation without interpreters, no sources without context, no text without paratext. Documents may encode data and key information currently not yet accessible or discernible. For various reasons, specific information can be virtually invisible for generations of scholars (e.g. blood cells, DNA, political attitudes, androcentrism, etc.). Old documents should be routinely re-analysed in light of new technologies or new interpretive frameworks (e.g. paleohistology, paleogenomics, evolutionary psychology, gender studies, etc.).

Documents are mute without historians. Progress in historiography is the result of ongoing inter-generational and free inquiry, qualitative assessment, critical peer review, comparative analyses, professional data gathering, archival or field research, etc. The more documents are available, the clearer the picture of the past - and, consequently, of the present. Keep always in mind that any claim requires a necessary and sufficient amount of supporting evidence and logical reasoning. Unsubstantiated claims that fall short of such standards, and thus fail to satisfy the required preconditions, can be rejected without providing any counter-argumentation. This does not mean that abduction, i.e. inference to the best explanation, is unacceptable, nor that having all the necessary data is sufficient to produce the best hypothesis: you can have all the data you want, but hypotheses are only as strong as their underlying philosophical assumptions - whether explicit or implicit.

Historical hypotheses need qualitative evaluation and/or quantitative testing for corroboration or rejection. Historiography progresses thanks to the ongoing check of previous interpretations. Documents can be untrustworthy; likewise, past and present scholars may have extra-epistemic

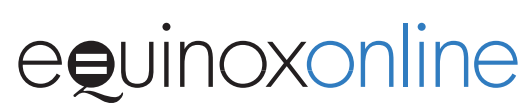


agendas. Historians are human beings, and human beings are biased. Always be mindful that institutions may be biased too: historically speaking, religious, cultural, and socio-political organizations have tended to exploit common-sense reasoning and intuitive biases to sieve cultural representations and favour certain views. No historian, no historical event, no document, no institution, and no hypothesis - no matter how cherished they may be - is immunized from critical investigation. As an effortful, collective and cumulative process, historiography, when done right, deals and copes effectively with such biases.

\section{Historiography is Science}

Historiography does not exist in a void. Human history is part of an entire class of historical sciences: cosmology, historical geology, palaeontology, palaeoanthropology, evolutionary biology, cultural geography, linguistics, epidemiology, etc.

Historical sciences differ from experimental sciences in that they are constrained by the entropic progress of time. Historical sciences overcome their inability to manipulate variables in controlled settings by resorting to a specific, reliable, epistemically warranted toolbox to investigate the multivariate relationship between cause and effect, as well as the emergence, modification, stability, resilience, and extinction of natural and cultural items through time. You cannot rerun the explosion of a supernova, the evolution of avian dinosaurs, or the fall of the Western Roman Empire in a lab, yet they can be studied as scientifically as the atomic structure of metals, photosynthesis, or gravitational force - provided that a consistent, coherent, and corroborated protocol is followed thoroughly.

Historiography needs philosophy of science. Method (analysis protocols and procedures) and theory (epistemology) are necessary for conducting the most reliable and updated research possible at the time being. Considering how multifaceted history is, this means that historical understanding grows if, and only if, it is supported by constant interdisciplinary collaboration and cross-disciplinary integration. To do so, the knowledge of the history of each disciplinary historiography is necessary to discern which research paths led nowhere and which deserve to be explored again. Mind the priority rule: usually, huge inter-disciplinary collaborative efforts gain multidisciplinary width but lose intra-disciplinary depth. To avoid naïve theorizing or the creation of new labels for purportedly new phenomena or theories already identified and studied in the past, the following suggestion applies: know your historiography.

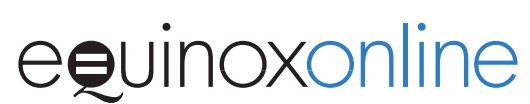




\section{Historiography needs Cognition}

Each human being has a mind - which is the product of an evolved brain. Historians have usually resorted to common-sense, folk-intuitive tools to understand the individual and social behaviours and the thinking of past historical agents. However, while intuition and mind-reading (or theory of mind) are powerful tools to discern the volition, desires, and goals of human agents, uncritical socio-cultural preconceptions, misplaced trust in the sources, and presentist prejudices can lead to imprecise, anachronistic, if not outright wrong, theorizing. Therefore, to unravel the complexity of historical cognition(s), historiography needs more brain and mind sciences. In order to help the successful accommodation of this cross-disciplinary graft, historiography needs a step-by-step consilient approach.

A consilient strategy to historical cognition entails, first and foremost, a neurohistorical approach. Cognition and behaviours change as the neurochemicals within the brain change - and H. sapiens, perhaps even more than other nonhuman animals, is particularly apt at altering, controlling, and subverting its neurochemical states through both consumption of food or drinks (or lack thereof) and enaction of collective or individual rituals and activities to elicit specific moods and emotions. Be always aware that such manipulations can be institutionally exploited to control subordinates.

Scientific consilience in historiography complements and expands - it does not eliminate - previously established disciplinary procedures. For instance, a full-fledged scientific approach need not renounce poststructuralist tools, provided that they are integrated thoughtfully. In both disciplinary scenarios, human beings are socially-biased, equally competitive and cooperative agents embedded in societal power relations. Add an evolutionary framework and the gap between the two scenarios will be bridged. But consilience also means that researchers have the responsibility to check constantly their toolbox, update what needs to be improved, keep what works and discard what does not. Case in point: while deconstruction offers a thought-provoking literary tool to reverse-engineer authorial intent, postmodern discursive criticism - according to which socio-linguistic meaningmaking processes and ever-changing reinterpretations relativize any search for facts or truth - confuses epistemology (i.e. the strategies we adopt to approach and study the way things are in the world out there) with ontology (i.e. the way things are in the world out there). This is the fourth capital sin of historical research. In this sense, the success of postmodernism offers at least four valuable lessons for cognitive historiography:

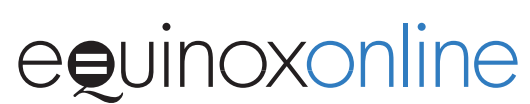


1. It represents an understandable reaction against outdated historiographical narratives

2. It epitomizes the human need to prioritize emotional storytelling and fictional narratives

3. It constitutes a cautionary tale about the impact of cognition-blind and science-free assumptions on historical critical thinking

4. It serves as a reminder of the socio-political jeopardy which follows from the cultural diffusion and weaponization of post-truth beliefs; e.g. neo-creationist accommodationism, climate change denialism, antivax advocacy, historical negationism, conspiracy theorizing, and policies based on all such "alternative facts"

\section{Cognition Matters}

Cognition is the evolutionarily selected, good-enough set of computational skills and mental heuristics that make sense of and help navigate both the social and natural worlds. As such, everything in human history relates to, informs, or results from cognition.

However, cognition-blind, intuitive approaches have always been a staple of historiography. Moreover, previous attempts at interpreting naturalistically the cognition and behaviours of historical agents have resulted in incomplete accounts, questionable results, or plain failure (e.g. psychohistory and phenomenology). These shortcomings, coupled with a marked indifference to neuroscience, have led to the historiographical neglect of cognitive science and philosophy of mind. Given that the premises were flawed a principio (i.e. the lacking scientific status of psychoanalytical theories and hermeneutical philosophies), and considering the outstanding advances in the scientific study of both mind and brain, this situation is unwarranted and unjustified.

This does not mean that the knowledge or the study of speculative, falsified, or pseudoscientific ideas, theories, and ideologies is useless. On the contrary, when properly contextualized, these are a most important resource in the historian's toolbox. H. sapiens construct, ascribe, and infer incessantly meaning and motives to both self and social actors through the lenses of culturally-learned fictional narratives, folk theories, explanatory worldviews, and virtual realities, whether religious or secular, emic or etic. Decisionmaking and individual or social identities literally depend on these cognitive assumptions. Neuroscience and cognitive sciences can clarify the ultimate causes behind the appeal of such ideas, but these disciplines cannot replace the necessary qualitative study to understand the emergence, development, and diffusion of these ideas (i.e. the proximate causes). Moreover, such a study can provide new insights on both the history of science and the history 
of ideas (e.g. the legacy of psychoanalysis in John Bowlby's attachment theory or Aaron T. Beck's cognitive behavioural therapy).

\section{Cognition is Multidimensional}

There is more to cognition than meets the eye. Cognition entails the following main dimensions: it is embodied (there is no mind without brain, and no brain without body), embedded (there is no cognition without extra-bodily and environmental interactions or processes), extended (physical objects are necessary to produce cognition), enactive (cognition results in the engagement of actions and behaviours), and, most importantly, encultured (the brain functions on the basis of a historically determined and learned set of beliefs, norms, practices, and worldviews).

Cognition builds on memory - the historical databank of previous events which accumulates to make up personal, social, and cultural identities. There is no history without cognition, and cognition is impacted by history in at least two ways: personal/ontogenetic (positive or negative developmental events determines life history strategies and adaptive or maladaptive coping strategies); social/phylogenetic (cognitive schemata and behavioural scripts change inter- and intra-generationally). History also determines the variety of synchronic structures and diachronic development of worldwide cultures. Ancient human communities developed their cultures on a "firstcome, first served" basis: because of relative geohistorical isolation and the cognitive grip of certain biases, cultural representations that came early constrained the development of subsequent innovations (or lack thereof), regardless of their (sub-)optimality.

Cognition is informed and informs both rational thinking and emotions - and vice versa. Logic and emotions need not be opposites: there can be no rational output without emotional input. Emotions constitute a most important heritage of our mammalian ancestry and they modulate both social relations and the production of culture. Therefore, as far as their actions are concerned, human beings cannot just be considered as rational choosers. Rather, they are emotionally primed, computationally limited, cognitively bounded, socially constrained, normatively coerced, economically naïve, and rationally misguided agents. This is why we need science to overcome such biases.

\section{Cognition needs a Deep-time Approach}

The Deep Time of evolution is the ultimate historiographical backdrop for studying cognition. The historical study of the mentalité across the longue

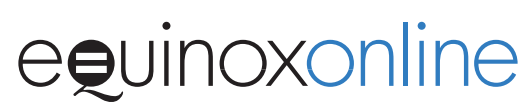


durée of human history overlaps today with Big History - that is, the whole of the historical sciences, from cosmology to the digital revolution. The very concepts of mentalité and longue durée have been radically transformed by this process: once reinserted within a bigger temporal frame, the "prisons" of slow-moving, almost unchangeable socio-cultural and ecological environments typical of conventional historical periodization become transient biocultural episodes of global (mal-)adaptation which span for hundreds of thousands of years. By the same token, there is no prehistory, just as there can be no posthistory. Instead, there are transitional thresholds which mark the complex, interactional emergence of new biocultural and biosocial configurations in all of history (e.g. hominin evolution, agriculture, sedentism, ultrasocial settlements, etc.).

A specific branch of Big History, i.e. Deep History, studies the ultimate, neuroendocrinological causes of human beliefs and behaviours, while conventional human history supplies the proximate real-life implementations, actualizations, interactions, and creations within and between cultures.

From a deep-time perspective, cognition is the result of good-enough, evolutionary tinkering or bricolage. Cognition is not infallible or flawless, as it offers potentially (mal-)adaptive computational outputs. As a collection of interlocked and interlinked modules or abilities subjected primarily to social pressures and secondarily to other evolutionary constraints, $H$. sapiens' problem-solving competences have limits and are marred by biases and logical fallacies. Yet, there are socio-cognitive ways to overcome such issues (e.g. science).

\section{Cognition needs Culture}

Cognition builds, sustains, and develops the collective web that ties together interpersonal social networks. Societies and sub-system institutional organizations are functional networks of interconnected brains (i.e. distributive cognition). Cultural representations and ideas percolate through this information system; their emergence, transmission, diffusion, modification, resilience, and extinction are the result of inborn attractors, innate cognitive expectations, historical contingencies, social constraints, and culturespecific preferences. Neurosociologically speaking, cultures are extended neural environments.

There is no real divide between nature and culture: they are two sides of the same Möbius strip. Cultural and behavioural (phenotypic) preferences, either the end result of chance or deliberate choice, might act as a selective force on future generations, affecting developmental learning processes and impacting both phenotypes and (in the long run) genotypes. Therefore,

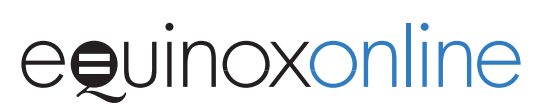


a modified cultural and cognitive niche can become part of social, intergenerational heredity through history (i.e. Baldwin Effect).

Religion does not constitute a distinct part of human culture. There is no neurocognitive difference between religion and other activities or ideologies (e.g. politics, sport fanaticism, fictional narratives, non-religious mythmaking in pop culture and media, etc.). There is no specific 'God spot' in the brain. The building blocks of religions such as ritual behaviours and cognitive inclinations are present in nonhuman primates. Culturally postulated superhuman agents (i.e. ancestors, ghosts, spirits, heroes, goddesses, gods, Fate, the charismatic leader, the Nation, etc.), although intuitively attention-grabbing, anxiety-decreasing, emotionally rewarding, and ideologically powerful, are relevant and meaningful as long as they satisfy a series of certain requirements and only in specific historical circumstances. In time, all of them, and all the societies that created and believed in them, die. Neurodiversity, contingent cultural preferences, socio-economic indicators, scientific literacy, presence or absence of warfare and social/class/ ethnic tensions, and overall quality of life modulate the degree to which the members of any population may or may not trust or accept those superhuman agents. However, considering the cognitively optimal "stickiness" of religion as an ancient, intuitively selected, and finely-honed mechanism for group-binding justification, neurosocial commitment, epistemic satisfaction, and (fictional) worldmaking, religion should always take centre-stage any time this is deemed relevant for social and historical analyses, especially considering the constant appeal and the role of religion in building social identities and supporting institutional systems of authority.

\section{Cognition needs History}

Imagined communities, the psychosocial outcome of societal networking and shared storytelling, subsume and institutionalize norms and rules. The resulting worldviews, which might be more or less (mal-)adaptive, bind together populations and they are always historically determined and temporary. Sometimes, the unbroken historical transmission of bundles of local belief-behaviour complexes can be historiographically confirmed (e.g. ancient myths or stories with a mnemonically adaptive value concerning how to avoid or minimize the effects of dangerous and recurrent geological events). However, peoples migrate, myths are lost, and cultural history is quasi-recursive: human societies can also adopt, adapt, retrieve, and mix cultural representations from their more or less distant past or from other societies past and present to (re)build their imagined communities. Comparison is a most powerful tool for all historical sciences, particularly apt

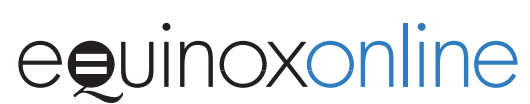


to investigate such a tangled web of cultural heritage and lore. There is a catch, though: whenever conducted intuitively, without adequate training in method and theory, comparison might lead to historical false positives, tracing relationships when there were none (e.g. ancient proto-Greek roots of pre-Columbian Native American cultures). Also, be alert to the fact that similar historical pressures can result in similar cultural outcomes: given the same panhuman set of socio-cognitive predispositions, cultural similarity does not always imply direct contact or common descent (e.g. the parallel and convergent evolution of ancient Egyptian and Mesoamerican pyramids).

Cognition is varied. As a consequence of historical differentiation, i.e. evolutionary and biological variation, neurodiverse or non-neurotypical cognitions and conditions are always to be expected in past and present societies (e.g. dyscalculia, dyslexia, aphantasia, amusia, alexithymia, Obsessivecompulsive disorder, Bipolar disorder, Autism spectrum conditions, etc.). Socio-cultural or religious coordinates and technological know-how (e.g. access to and mastery of literacy or specific cognitive-behavioural techniques) determine if and how neurodiverse individuals have the opportunity to express themselves, while also determining the degree of their individual fitness and the level to which the body politic accommodate, assist, reject, or refuse to acknowledge their opinions and their needs (e.g. shamanism, Fools for Christ, etc.). In any case, absence of neurodiversity evidence does not mean evidence of its absence. Also, the institutional implementation of certain socio-political decisions may consciously or unconsciously impact the neurocognitive development of individuals for generations to come, mimicking or overlapping with other genetic impairments (e.g. psychosocial deprivations resulting in quasi-autism disorders), and affecting society as a whole (cf. congenital abnormalities caused by consanguineous marriages supported by local religious or cultural traditions: e.g. brother-sister marriage in ancient Egypt, incest according to Zoroastrian customs, royal intermarriage and inbreeding in modern European nobility, etc.). In this respect, particular attention should be paid to the historical link between cultural and political contexts, mental health, and psychopathology at both societal and individual level. We would expect higher rates of specific mental disorders in specific socio-historical configurations because of specific socio-political implementations and technological innovations (e.g. 21st-century digital technology, social media, consumerism, and pollution seemingly correlated with distinct patterns of anxiety disorders, cognitive impairment, and depression; intuitive preference for psychopathic traits by Human Resources recruitment to boost competitiveness and risk-taking behaviours in corporate capitalism, etc.). In all these cases, neurocognitive 
scientists beware: whether directly or indirectly, brains have a maturational, developmental, and social history which explains their functioning, fallibility, and limitations.

The interaction of history and cognition does not come as "one size fits all." There is a chronological continuum, and different levels of interplay. Temporarily stable imagined communities and their worldviews can be somewhat immune to the reception of other ideas and constitute what could be called mesohistory. Mesohistory bridges together microhistory (i.e. the neurosociological mechanisms of network interactions by which ideas are transmitted and modified) and macrohistory (i.e. the longue-durée coevolution between culture and biology). Critical thinking and cognition also lead to historiographical meta-awareness: the same toolbox used to investigate historical behaviours and beliefs can be used to reverse-engineer the scholars' own biases. The systematic synthesis of all these diachronic and synchronic dimensions is the task that awaits cognitive historians.

\section{Aknowledgements}

The author would like to thank his fellow JCH co-editors Luther H. Martin, Esther Eidinow and Nickolas Roubekas, as well as Mathias Clasen and Elisabeta Pop, for their valuable feedback and suggestions.

Disclaimer: the views and opinions expressed in the present article are the author's and do not necessarily reflect the views or the position of the other members of the $\mathrm{JCH}$ editorial board.

\section{Endnote}

1. Leonardo Ambasciano earned his $\mathrm{PhD}$ in Historical Studies at the University of Turin, Italy, in 2014 with a cognitive and evolutionary analysis of the ancient Roman female cult of Bona Dea. In 2016, he was Visiting Lecturer in Religious Studies at Masaryk University, Brno, Czech Republic. He is the author of An Unnatural History of Religion: Academia, Post-Truth, and the Quest for Scientific Knowledge (London: Bloomsbury, 2018), and of various articles, book reviews, and chapters, the most recent of which is "Politics of Nostalgia, Logical Fallacies, and Cognitive Biases: The Importance of Epistemology in the Age of Cognitive Historiography", in A New Synthesis for the Study of Religion: Cognition, Evolution, and History in the Study of Religion, edited by I. S. Gilhus, J. S. Jensen, L. H. Martin, J. Sørensen and A. K. Petersen (Leiden: Brill, 2018).

\section{Reading List}

Ambasciano, L. 2018. An Unnatural History of Religions: Academia, Post-truth and the Quest for Scientific Knowledge. London and New York: Bloomsbury.

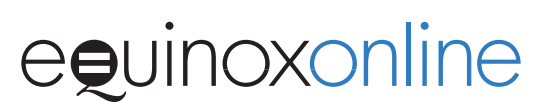


Ambasciano, L., and T. J. Coleman III. 2019. "History as a Canceled Problem? Hilbert Lists, du Bois-Reymond's Enigmas, and the Scientific Study of Religion”. Journal of the American Academy of Religion 87(2): 366-400. https://doi.org/10.1093/jaarel/lfz001

Anderson, B. 1991. Imagined Communities: Reflections on the Origin and Spread of Nationalism. Revised Edition. London: Verso.

Arnold, J. H. 2000. History: A Very Short Introduction. Oxford: Oxford University Press.

Astuti, R., and M. Bloch. 2012. "Anthropologists as Cognitive Scientists". Topics in Cognitive Science 4(3): 453-61. https://doi.org/10.1111/j.1756-8765.2012.01191.x

Barber Wayland, E., and P. T. Barber. 2006. When They Severed Earth from Sky: How the Human Mind Shapes Myth. Princeton, NJ and Oxford: Princeton University Press. https://doi.org/10.1086/509695

Baron-Cohen, S., M. Lombardo, and H. Tager-Flusberg, eds. 2018. Understanding Other Minds: Perspectives from Developmental Social Neuroscience. Third Edition. Oxford: Oxford University Press. https://doi.org/10.1093/acprof:oso/9780199692972.001.0001

Bechtel, W., A. Abrahamsen and G. Graham. 2001. "Cognitive Science, History”. In International Encyclopedia of the Social and Behavioral Sciences, eds. N. J. Smelser and P. B. Baltes, 2154-158. Oxford: Elsevier Science. https://doi.org/10.1016/b0-08-043076-7/014 $42-\mathrm{x}$

Boudry, M., and M. Pigliucci, eds. 2017. Science Unlimited? The Challenges of Scientism. Chicago and London: The University of Chicago Press. https://doi.org/10.1007/s11191 -019-00037-1

Braudel, F. 1980. "History and the Social Sciences: The Longue Durée”. In On History. Translated by S. Matthews, 25-54. Chicago: The University of Chicago Press. Originally published in 1958 as "Histoire et sciences socials. La longue durée". Annales. Économies, Sociétés, Civilisations 13(4): 725-53. https://doi.org/10.3406/ahess.1958.2781. Reprinted in 1969 in Écrits sur l'histoire, 41-83. Paris: Flammarion. https://doi.org/10.3406/ahess .1958 .2781

Brüne, M. 2016. Textbook of Evolutionary Psychiatry \& Psychosomatic Medicine: The Origins of Psychopathology. Second Edition. Oxford: Oxford University Press.

Bulbulia, J., and E. Slingerland. 2012. "Religious Studies as a Life Science". Numen: International Review for the History of Religions 59(5-6): 564-613. https://doi.org/10.1163/1568 5276-12341240

Burguière, A. 2009. The Annales School: An Intellectual History. Translated by J. M. Todd. Ithaca and London: Cornell University Press. Originally published in 2006 as L'école des Annales. Une histoire intellectuelle. Paris: Odile Jacob. https://doi.org/10.1086/60 5133

Burman, J. T. 2014. "Bringing the Brain into History: Behind Hunt's and Smail's Appeals to Neurohistory”. In Psychology and History: Interdisciplinary Explorations, eds. C. Tileagă and J. Byford, 64-82. Cambridge and New York: Cambridge University Press. https:// doi.org/10.1017/СBO9781139525404.006

Butterworth, B. 1999. The Mathematical Brain. London: Macmillan.

Carroll, J. 2018. "Minds and Meaning in Fictional Narratives: An Evolutionary Perspective". Review of General Psychology 22(2): 135-46. https://doi.org/10.1037/gpr0000104

Chatfield, T. 2018. Critical Thinking. Los Angeles, CA and London: SAGE Publications.

Christian, D. 2011. Maps of Time: An Introduction to Big History. With a New Preface. Berkeley, Los Angeles, CA and London: University of California Press.

Collingwood, R. G. 1989. The Idea of History. Oxford: Oxford University Press. Originally published in 1946 (Oxford: Clarendon Press).

Cover, J. A., M. Curd, and C. Pincock, eds. 2012. Philosophy of Science: The Central Issues. Second Edition. New York: W.W. Norton \& Co. 
Crawford, M. ed. 1985. The Sources of History. Cambridge: Cambridge University Press.

Currie, A. 2016. "Ethnographic Analogy, the Comparative Method, and Archaeological Special Pleading”. Studies in History and Philosophy of Science Part A (55): 84-94. https:// doi.org/10.1016/j.shpsa.2015.08.010

D'Ancona, M. 2017. Post-Truth: The New War on Truth and How to Fight Back. London: Ebury Press.

Dennett, D. C. 2006. Breaking the Spell: Religion as a Natural Phenomenon. New York: Viking.

Diamond, J., and J. Robinson, eds. 2010. Natural Experiments of History. Cambridge, MA and London: The Belknap Press of Harvard University Press.

DiMaggio, P. 1997. "Culture and Cognition". Annual Review of Sociology 23: 263-87. https:// doi.org/10.1146/annurev.soc.23.1.263

Dunbar, R. I. M. 2014. Human Evolution. London: Penguin.

Eidinow, E., and L. H. Martin. 2014. “Editors' Introduction”. Journal of Cognitive Historiography 1(1): 5-9. https://doi.org/10.1558/jch.vli1.5

Evans, R. J. 2000. In Defence of History. New Edition. London: Granta. Originally published in 1997.

Fedyk, M. 2015. "How (Not) to Bring Psychology and Biology Together". Philosophical Studies 172(4): 949-67. https://doi.org/10.1007/s11098-014-0297-9

Ferraris, M. 2014. Manifesto of New Realism. Translated by S. De Sanctis. Albany, NY: State University of New York Press. Originally published in 2012 as Manifesto del nuovo realismo. Rome and Bari.

Ferraris, M. 2017. Postverità e altri enigmi. Bologna: il Mulino.

Fischer, D. H. 1970. Historians' Fallacies: Toward a Logic of Historical Thought. New York and London: Harper Perennial.

Gaddis, J. L. 2002. The Landscape of History: How Historians Map the Past. Oxford: Oxford University Press.

Geertz, A. W. 2010. "Brain, Body and Culture: A Biocultural Theory of Religion". Method \& Theory in the Study of Religion 22(4): 304-21. https://doi.org/10.1163/157006810X531094

Geertz, A. W. 2015. "Religious Belief, Evolution of". In International Encyclopedia of the Social \& Behavioral Sciences. 2nd edition, J. D. Wright (editor-in-chief), Vol 20, 384-95. Oxford: Elsevier. http://dx.doi.org/10.1016/B978-0-08-097086-8.81055-7

Gottschall, J. 2012. The Storytelling Animal: How Stories Make Us Human. Boston and New York: Houghton Mifflin Harcourt.

Gould, S. J. 1986. "Evolution and the Triumph of Homology, or Why History Matters". American Scientist 74(1): 60-69. https://www.jstor.org/stable/27853941

Gould, S. J. 2002. "Freud's Evolutionary Fantasy". In I Have Landed: The End of a Beginning in Natural History, 147-58. New York: Harmony Books. Originally published in 1987 as "Freud's Phylogenetic Fantasy: Only Great Thinkers Are Allowed to Fail Greatly", Natural History 96(12): 10, 14, 16, 18, 19. https://doi.org/10.4159/harvard.9780674063419

Jacob, F. 1977. "Evolution and Tinkering". Science 196(4295): 1161-66. http://dx.doi.org/10 $.1126 /$ science. 860134

Jensen, J. S. 2014. What Is Religion? London and New York: Routledge.

Kennerley, H., J. Kirk and D. Westbrook. 2017. An Introduction to Cognitive Behaviour Therapy. Los Angeles, CA and London: SAGE Publications.

Laplane, L., P. Mantovani, R. Adolphs, H. Chang, A. Mantovani, M. McFall-Ngai, et al. 2019. "Opinion: Why Science Needs Philosophy". Proceedings of the National Academy of Sciences 116(10): 3948-952. https://doi.org/10.1073/pnas.1900357116

Lincoln, B. 1996. "Theses on Method". Method \& Theory in the Study of Religion 8(3): 225-27. https://doi.org/10.1163/157006896X00323

\section{eevinoxonline}


Lincoln, B. 2000. "Culture". In Guide to the Study of Religion, ed. W. Braun and R. T. McCutcheon, 409-22. London: Cassell.

Martin, L. H. 2014. Deep History, Secular Theory: Historical and Scientific Studies of Religion. Boston and Berlin: De Gruyter. https://doi.org/10.1515/9781614515005

Martin, L. H., and J. Sørensen, eds. 2011. Past Minds: Studies in Cognitive Historiography. London and New York: Routledge. https://doi.org/10.4324/9781315478371

McCauley, R. N. 2011. Why Religion Is Natural and Science Is Not. New York: Oxford University Press.

McCauley, R. N. 2017. Philosophical Foundations of the Cognitive Science of Religion: A Head Start. With a Chapter Co-written with E. T. Lawson. London and New York: Bloomsbury.

McCutcheon, R. T. 1997. Manufacturing Religion: The Discourse on Sui Generis Religion and the Politics of Nostalgia. Oxford: Oxford University Press.

Momigliano, A. 2016. "The Rules of the Game in the Study of Ancient History". Translated by K. W. Yu. History \& Theory 55(1): 39-45. Originally published in 1974 as "Le regole del giuoco nello studio della storia antica", Annali della Scuola Normale Superiore di Pisa, Cl. Lett. e Fil., Serie III(4): 1183-192. https://doi.org/10.1111/hith.10786

Monod, J. 1972. Chance and Necessity: An Essay on the Natural Philosophy of Modern Biology. Translated by A. Wainhouse. New York: Vintage. Originally published in 1970 as Le hasard et la nécessité. Paris: Éditions du Seuil. https://doi.org/10.1086/407100

Newen, A., L. De Bruin and S. Gallagher, eds. 2018. The Oxford Handbook of 4 E Cognition. Oxford: Oxford University Press. https://doi.org/10.1093/oxfordhb/9780198735410.001 .0001

O’Rourke, M., S. Crowley and C. Gonnerman. 2016. "On the Nature of Cross-disciplinary Integration: A Philosophical Framework". Studies in History and Philosophy of Science Part C: Studies in History and Philosophy of Biological and Biomedical Sciences 56: 62-70. https://doi.org/10.1016/j.shpsc.2015.10.003

Panksepp, J., and L. Biven. 2012. The Archaeology of Mind: Neuroevolutionary Origins of Human Emotion. New York: W.W. Norton \& Co.

Petersen, A. K. et al. eds. 2018. Evolution, Cognition, and the History of Religion: A New Synthesis. Leiden and Boston: Brill.

Pigliucci, M., and M. Boudry, eds. 2013. Philosophy of Pseudoscience: Reconsidering the Demarcation Problem. Chicago and London: University of Chicago Press. https://doi .org/10.7208/chicago/9780226051826.001.0001

Pinker, S. 2010. "The Cognitive Niche: Coevolution of Intelligence, Sociality, and Language". Proceedings of the National Academy of Sciences 107 (Supplement 2): 8993-999. https:// doi.org/10.1073/pnas.0914630107

Plotkin, H. 2004. Evolutionary Thought in Psychology. Oxford: Blackwell.

Richerson P. J., and M. H. Christiansen, eds. 2013. Cultural Evolution: Society, Technology, Language, and Religion. Cambridge, MA and London: The MIT Press.

Rovelli, C. 2011. The First Scientist: Anaximander and His Legacy. Yardley, PA: Westholme Publishing. Originally published in 2009 as Anaximandre du Milet, ou la naissance de la pensée scientifique. Paris: Dunod.

Russell, E. 2011. Evolutionary History: Uniting History and Biology to Understand Life on Earth. Cambridge: Cambridge University Press. https://doi.org/10.1017/cbo978051197 4267

Sagan, C. 1996. The Demon-Haunted World: Science as a Candle in the Dark. New York: Ballantine Books.

Scheidel, W. 2014. "Evolutionary Psychology and the Historian". The American Historical Review 119(5): 1563-75. https://doi.org/10.1093/ahr/119.5.1563 
Shermer, M., and A. Grobman. 2009. Denying History: Who Says the Holocaust Never Happened and Why Do They Say It? Updated and Expanded. Berkeley, Los Angeles, CA and London: University of California Press. https://doi.org/10.1093/hgs/16.2.321

Shettleworth. S. J. 2010. Cognition, Evolution, and Behavior. Second Edition. Oxford and New York: Oxford University Press.

Shryock, A., and D. L. Smail, eds. 2011. Deep History: The Architecture of Past and Present. Berkeley, Los Angeles, CA and London: University of California Press.

Slingerland, E., and M. Collard, eds. 2012. Creating Consilience: Integrating the Sciences and the Humanities. Oxford and New York: Oxford University Press.

Smail, D. L. 2008. On Deep History and the Brain. Berkeley, Los Angeles, CA and London: University of California Press.

Sørensen, J. 2004. "Religion, Evolution and an Immunology of Cultural Systems. Evolution and Cognition 10(1): 61-73.

Sperber, D. 2011. "A Naturalistic Ontology for Mechanistic Explanations in the Social Sciences". In Analytical Sociology and Social Mechanisms, ed. P. Demeulenaere, 64-77. Cambridge and New York: Cambridge University Press. https://doi.org/10.1017/cbo978 0511921315.004

Sulloway, F. J. 1992. Freud, Biologist of the Mind: Beyond the Psychoanalytic Legend. With a New Preface by the Author. Cambridge, MA and London: Harvard University Press.

Sulloway, F. J. 1998. Born to Rebel: Birth Order, family Dynamics, and Creative Lives. London: Abacus.

Turner, J. H., A. Maryanski, A. K. Petersen and A. W. Geertz. 2018. The Emergence and Evolution of Religion by Means of Natural Selection. London and New York: Routledge. https://doi.org/10.4324/9781315111995

Turner, M., and G. Fauconnier. 2002. The Way We Think: Conceptual Blending and the Mind's Hidden Complexities. New York: Basic Books. https://doi.org/10.1086/378014

Weinstein, F. 1995. "Psychohistory and the Crisis of the Social Sciences". History and Theory 34(4): 299-319. https://doi.org/10.2307/2505404

White, L. A. 1938. "Science is Sciencing”. Philosophy of Science 5(4): 369-89. https:// www.jstor.org/stable/184653

Whiten, A., R. A. Hinde, C. B. Stringer and K. N. Laland, eds. 2012. Culture Evolves. Oxford: Oxford University Press. https://doi.org/10.1093/acprof:osobl/9780199608966.001.0001

Wiebe, D. 1999. The Politics of Religious Studies: The Continuing Conflict with Theology in the Academy. New York: St. Martin's Press.

Wilson, R. A., F. C. Keil, eds. 1999. The MIT Encyclopedia of the Cognitive Sciences. Cambridge, MA and London: The MIT Press.

Wyatt, F. 1961. “A Psychologist Looks at History”. Journal of Social Issues 17(1): 66-77. https://doi.org/10.1111/j.1540-4560.1961.tb01664.x 